\title{
EFFECTS OF DIFFERENT WATER STRESS LEVELS ON BIOMASS YIELD AND AGRONOMIC TRAITS OF SWITCHGRASS (Panicum virgatum L.) VARIETIES UNDER SEMI-ARID CONDITIONS*
}

\author{
Erdal GONULAL ${ }^{1}$, Suleyman SOYLU ${ }^{2}$, Mehmet SAHIN ${ }^{3}$ \\ ${ }^{1}$ Bahri Dagdas International Agriculture Research Institute, Konya, TURKEY \\ ${ }^{2}$ Selcuk University, Faculty of Agriculture, Department of Field Crops, Konya, TURKEY \\ ${ }^{3}$ Selcuk University, Faculty of Agriculture, Department of Agricultural Structures and Irrigation, Konya, \\ TURKEY \\ Corresponding author's e-mail: erdalgonulal@hotmail.com. \\ *derived from the Ph.D. Thesis of the Senior Author
}

Received: 25.06 .2020

\begin{abstract}
This experiment was conducted to determine the effects of different water stress levels on biomass yield, plant height, number of stalks per meter, single stalk weight, yield reduction ratios and irrigation water use efficiency (IWUE) values of switchgrass (Panicum virgatum L.) varieties under Central Anatolia conditions. The study was conducted for two years $(2016$ - 2017) in the Randomized Complete Block Design arranged in split plots with three replications under Konya ecological conditions. Six switchgrass varieties (Shelter, Alamo, Cave in rock, Shawnee, Kanlow and Trailblazer) and five different irrigation treatments (water stress levels: S1: Full irrigation; S2: $75 \%$ of full irrigation; S3: $50 \%$ of full irrigation; S4: $25 \%$ of full irrigation and S5: Rain-fed without irrigation) were used in this experiment.

Kanlow, Alamo and Trailblazer varieties had greater biomass yields than the other varieties in all water stress treatments. Under different water stress treatments, dry biomass yields varied between $48300 \mathrm{~kg}$ ha-1 (S5- Cave in rock) and $25120 \mathrm{~kg}$ ha-1 (S1- Kanlow); plant heights varied between $70 \mathrm{~cm}(\mathrm{S5})$ and $180 \mathrm{~cm}(\mathrm{S1})$; number of stalks per meter varied between 221 (S5) and 356 (S1); single stalk weights varied between $0.56 \mathrm{~g}$ (S5) and 2.25 g (S1). IWUE was calculated as $5.7 \mathrm{~kg} \mathrm{~m}-3$ for the first harvest and as $2.1 \mathrm{~kg} \mathrm{~m}-3$ for the second harvest. Considering the biomass yields from single harvest of rain-fed treatments (S5) and two harvests of the other irrigation treatments (S1-S4), IWUE values and water deficits of the region, it was concluded that single harvest was more suitable for switchgrass plants grown under ecological conditions.
\end{abstract}

Keywords: Biomass yield, climate change, switchgrass, water stress, yield components.

\section{INTRODUCTION}

In Turkey, Central Anatolia region and especially the Konya basin is the arid region. The basin has quite low annual precipitation and water resources are not sufficient to irrigate the agricultural lands. Konya basin has 1.8 billion $\mathrm{m}^{3}$ available water potential, but annual amount of water used in the region is around 2.6 billion $\mathrm{m}^{3}$ (Anonymous, 2009). Therefore, there is a significant water deficit in the basin and such a case exerts serious threats on sustainability of water resources. Irregular and decreasing precipitations also decrease ground and surface water resources (Anonymous, 2009). Konya basin constitutes about 10\% of agricultural lands of Turkey. Together with plant production, number of livestock also increased especially with state supports provided for agricultural sector. Such an increase in livestock inventory increased forage needs significantly. However, it is quite hard to meet such increasing needs with crop species grown under rain-fed conditions or crop species with less water consumptions.

Switchgrass is a perennial, environment-friendly warm season crop with a high water use efficiency (Xu et al., 2006), able to produce biomass under marginal and arid and semi-arid conditions (Parrish and Fike, 2005) and prevent soil erosion. Therefore, it is commonly used as low-cost silage material and forage source. Since it has quite a high biomass production capacity, it is also used in establishment of artificial pasture and in pasture improvement practices (Ma et al., 2000). There are two different ecotypes of switchgrass based on morphological characteristics and growing environments as of: upland (highland type) and lowland (plain type). Plant heights of switchgrass varies between 1-3 m. Lowland ecotypes generally have higher plant heights, thicker stalks and greater biomass and they are mostly used for bioethanol. 
On the other hand, upland ecotypes are shorter plant heights, greater number of tillers, thinner stalks and they are mostly used as forage crop (Soylu et al., 2010).

North America-originated switchgrass is able to produce quite a high number of seeds, highly tolerant to cold and drought and has quite a high adaptation capacity. Soylu et al. (2010) conducted adaptation and growing experiments with switchgrass (Panicum virgatum L.) under Konya ecological conditions and obtained promising outcomes. Since switchgrass has less water use and able to grow under marginal conditions, it can be considered as an alternative forage crop in Konya basin with deficit irrigation levels.

This experiment was conducted to investigate the effects of different irrigation levels on yield and some yield components of six switchgrass varieties in Karapinar district of Konya province of Turkey. This region has high agricultural potential area but irregular and decreasing precipitation and insufficient water resources are important issues in this region. Alternative forage crop species that tolerant of drought is an important issue for this region.

\section{MATERIALS AND METHODS}

Experiment was conducted in Konya-Karapinar region $\left(37^{\circ} 41^{\prime} \mathrm{N}\right.$ and $\left.33^{\circ} 30^{\prime} \mathrm{E}\right)$ for two years in 2016 and 2017. Six different switchgrass varieties obtained from USDA (United States Department of Agriculture) and foreign companies were used as the plant material of the experiments. Two of these varieties (Kanlow- Alamo) were lowland ecotypes commonly used for bioethanol production and four of them (Shawnee, Shelter, Trailblazer and Cave in rock) were upland ecotypes commonly used for forage production or grazing.

Long-term annual average precipitation of the experimental site is $291.12 \mathrm{~mm}$ and majority of this precipitation falls out of the growing season of switchgrass (November - April). Total precipitation was $286.2 \mathrm{~mm}$ in 2016 and $249.6 \mathrm{~mm}$ in 2017 and both values were lower than the long-term average. The lowest temperature was observed as $-19.2{ }^{\circ} \mathrm{C}$ in January of 2016 and as $-18.7^{\circ} \mathrm{C}$ in February of 2017. These values were lower than the longterm average $\left(-18.2{ }^{\circ} \mathrm{C}\right.$ in January). Thus, the extreme cold resistance of switchgrass varieties was also seen.

Soil samples were taken from 0-30, 30-60 and 60-90 cm soil profiles of the experimental site. Analyses revealed that experimental soils were sandy-clay-loam in texture with lime contents of between $28.9-33.5 \%$ (high), $\mathrm{pH}$ values of between 7.8 - 8.2, organic matter contents of between 0.7 1.3 (low) and salinity levels of between $0.42-0.45 \mathrm{dS} \mathrm{m}^{-1}$ (unsaline). Soil bulk density was $1.37 \mathrm{~g} \mathrm{~cm}^{-3}$ for $0-30 \mathrm{~cm}$ layer, $1.29 \mathrm{~g} \mathrm{~cm}^{-3}$ for $30-60 \mathrm{~cm}$ layer and $1.22 \mathrm{~g} \mathrm{~cm}^{-3}$ for $60-90 \mathrm{~cm}$ layer. Soil infiltration rate was measured as 10 $\mathrm{mm} \mathrm{h}^{-1}$.

The seeds were planted on 1st of July, 2015. In establishment year, fertilizers were applied at sowing as to have $100 \mathrm{~kg} \mathrm{P} 205$ and $30 \mathrm{~kg} \mathrm{~N}$ per hectare. Considering germination and dormancy, it was planted with 400 plant m-2 (Soylu et al., 2010). Seeds were planted manually to 1 $\mathrm{cm}$ depth $15 \mathrm{~cm}$ row spacing and seedbeds were compacted. Experimental plots were $5 \mathrm{~m}$ long and $1.5 \mathrm{~m}$ wide $(5 \times 1.5=7.5 \mathrm{~m} 2)$ and each plot had 10 rows. At the harvest, two rows from both side and $1 \mathrm{~m}$ sections from the top and bottom of the plots were omitted (harvest was made from $2.7 \mathrm{~m} 2$ ). The design of the experiment was the Randomized Complete Blocks arranged in split plots with 3 replications ( 5 water stress treatments x 6 varieties x 3 replicates $=90$ plots $)$. Main plots included water stress treatments (S1, S2, S3, S4 and S5) and sub-plots included switchgrass varieties (Kanlow, Alamo, Shelter, Trailblazer, Cave in rock and Shawnee). In full irrigation treatment (S1), irrigation water was applied when the $50-55 \%$ of available water capacity was depleted as to bring the soil moisture level to field capacity. In water stress treatments (S2, S3 and S4), respectively 75,50 and $25 \%$ of full irrigation were applied. Irrigation was not practiced in rainfed treatment (S5).

In establishment year between the planting (1 July 2015) and the end of September, $150 \mathrm{~mm}$ irrigation water was applied to each plot with sprinkler (the initial one) and drip irrigation systems as to provide homogeneous germination and emergence. In the establishment year, harvest was made $15 \mathrm{~cm}$ above the ground surface and winter was passed through. In the experiment, different water stress treatments were applied in 2016 and 2017 years. In both years, $150 \mathrm{~kg} \mathrm{ha}^{-1}$ pure nitrogen was applied to experimental plots in May (Soylu et al., 2010).

Except for $\mathrm{S}_{5}$ treatment, two cuttings were made in other irrigation treatments $\left(S_{1}, S_{2}, S_{3}\right.$ ve $\left.S_{4}\right)$. The first cutting was made a week after $50 \%$ flowering stage as specified by Soylu et al. (2010) $15 \mathrm{~cm}$ above the ground surface with a motor scythe. Then harvested plants were weighed to determine fresh biomass yield of the first cutting. Irrigations were continued until the second harvest. Considering early autumn frosts, the second cutting was made on 19 October in 2016 and 10 October in 2017 and fresh biomass yield of the second cutting was determined.

For dry matter ratio, as specified by Muir et al. (2001), $500 \mathrm{~g}$ sample was weighed and dried in an oven at $70{ }^{\circ} \mathrm{C}$ for 48 hours. Dry mater ratio was then multiplied by fresh biomass yield to determine dry biomass yield. Harvest date, plant height, number of stalks per meter and single stalk weights were determined according to the method applied by Muir et al. (2001).

Drip irrigation system was used to irrigate switchgrass plants. Amount of irrigation water applied to each plot was measured with a water meter. Irrigations were initiated when the $50-55 \%$ of the available water within $90 \mathrm{~cm}$ effective root zone was depleted. The first irrigation was practiced on 4th of May in 2016 and 17th of May in 2017. The last irrigation was practiced on $7^{\text {th }}$ of September in 2016 and $20^{\text {th }}$ of September in 2017. Following the determination of soil bulk density, field capacity and permanent wilting point, amount of irrigation water to be 
applied in full irrigation treatment $\left(\mathrm{S}_{1}\right)$ was calculated with the use of Equation 1 (Kara, 2011);

$$
d n=\underline{(F C-C M) \times D}
$$

where; $\mathrm{dn}=$ Net amount of irrigation water to be applied in each irrigation $(\mathrm{mm})$;

$\mathrm{FC}=$ Field capacity (\% volume basis $)$

$\mathrm{CM}=$ Current moisture when the $50-55 \%$ of available water within $90 \mathrm{~cm}$ rooting zone was depleted (\% volume);

$\mathrm{D}=$ Effective root depth $(\mathrm{mm})$.

Equation 2 was used to determine yield reduction ratio (Golestani and Assad, 1998);

$\mathrm{Yr}=1-(\mathrm{Ys} / \mathrm{Yp})$.

where; $\mathrm{Yr}=$ Yield reduction ratio $(\%)$;

Ys $=$ Yield under stress $\left(\mathrm{kg} \mathrm{da}^{-1}\right)$;

$\mathrm{Yp}=$ Yield under irrigated conditions $\left(\mathrm{kg} \mathrm{da}^{-1}\right)$.

In the experiment, the following equation (Equation 3) was used to determine irrigation water use efficiency (Howell et al., 1990):

IWUE $=\mathrm{Y} / \mathrm{I}$ $3)$;

where; IWUE = Irrigation water use efficiency $(\mathrm{kg} \mathrm{m}$

$\mathrm{Y}=$ Dry biomass yield $\left(\mathrm{kg} \mathrm{da}^{-1}\right)$;

$\mathrm{I}=$ Irrigation water quantity $(\mathrm{mm})$.

Statistical analysis of experimental data was conducted using the JMP 11.2 statistical software according to Randomized Complete Block Design in split plots, and the LSD test was used to compare the means as described by Steel and Torrie (1980).

\section{RESULTS AND DISCUSSION}

This experiment was conducted for two years to investigate the effects of water stress treatments on biomass yield, some yield components, irrigation water use efficiency and yield reduction ratios of different switchgrass varieties. Data were initially subjected to homogeneity tests and then combined years were subjected to variance analysis. Fresh and dry biomass yield, plant height, number of stalks per meter, single stalk weight, irrigation water use efficiency and yield reduction ratio were significantly affected by water stress levels. Data were provided in tables as the average of two years and LSD $(0.05)$ groupings were provided accordingly.

\section{The amount of irrigation water}

Applied amount of irrigation water in both years are given in Table 1. In the experiment, amount of irrigation water varied between $176.5-704 \mathrm{~mm}$ in 2016 and between $281-800 \mathrm{~mm}$ in 2017.

Table 1. Applied irrigation water quantities (mm)

\begin{tabular}{|c|c|c|c|c|c|c|}
\hline Years & Irrigation period & $\mathbf{S}_{1}$ & $\mathbf{S}_{\mathbf{2}}$ & $\mathbf{S}_{\mathbf{3}}$ & $\mathbf{S}_{\mathbf{4}}$ & $\mathbf{S}_{5}$ \\
\hline \multirow{3}{*}{2016} & Irrigation water quantity until the first harvest & 490 & 367.5 & 245 & 123 & 0 \\
\hline & Irrigation water quantity between the first and second harvest & 214 & 160.5 & 107 & 53.5 & 0 \\
\hline & Total & 704 & 528 & 352 & 176.5 & \\
\hline \multirow{3}{*}{2017} & Irrigation water quantity until the first harvest & 436 & 327 & 218 & 109 & 0 \\
\hline & Irrigation water quantity between the first and second harvest & 364 & 273 & 182 & 91 & 0 \\
\hline & Total & 800 & 600 & 400 & 281 & \\
\hline \multirow{3}{*}{ 2016-17 avr. } & Irrigation water quantity until the first harvest & 463 & 347.3 & 231.5 & 115.8 & 0 \\
\hline & Irrigation water quantity between the first and second harvest & 289 & 216.8 & 144.5 & 72.3 & 0 \\
\hline & Total & 752 & 564.1 & 376 & 188.1 & \\
\hline
\end{tabular}

\section{Fresh and dry biomass yields of the first harvest}

The fresh and dry biomass yields of the first harvest are given in Table 2. As the average of two years, fresh biomass yields of the varieties varied between $33880 \mathrm{~kg} \mathrm{ha}^{-1}$ (Cave in rock) and $58300 \mathrm{~kg} \mathrm{ha}^{-1}$ (Kanlow) and dry biomass yields varied between $10080 \mathrm{~kg} \mathrm{ha}^{-1}$ (Cave in rock) and $16440 \mathrm{~kg}$ $\mathrm{ha}^{-1}$ (Kanlow). Trailblazer variety with thin stalk structure and potential use as forage crop was also prominent with fresh biomass yield of $42120 \mathrm{~kg} \mathrm{ha}^{-1}$ and dry biomass yield of $13330 \mathrm{~kg} \mathrm{ha}^{-1}$ just after Kanlow and Alamo varieties (Table 2).
As it was in previous experiments (Seflek, 2010; Zhu et al., 2014), lowland ecotypes of Kanlow and Alamo varieties had greater fresh and dry biomass yields than the upland ecotypes. Nasso et al. (2015) conducted an experiment in Italy and reported that dry biomass yields as $32500 \mathrm{~kg} \mathrm{ha}^{-1}$ for lowland ecotype Alamo variety and as $16500 \mathrm{~kg} \mathrm{ha}^{-1}$ for upland ecotype Blackwell variety. In another experiment conducted in Mediterranean climate zone, Wullschleger et al. (2010) reported dry biomass yield as $9000 \mathrm{~kg} \mathrm{ha}^{-1}$ for upland ecotypes and as $13000 \mathrm{~kg} \mathrm{ha}^{-1}$ for lowland ecotypes. Contrary to in this experiment results, Geren et al. (2016) reported that Cave in rock variety had high biomass yield in their experiment. This result is due to probably because of differences in climate 
and soil conditions and agronomic practices (Nasso et al., 2015).

Table 2. Fresh and dry biomass yields of the first harvest $\left(\mathrm{kg} \mathrm{ha}^{-1}\right)$

\begin{tabular}{|c|c|c|c|c|c|c|c|c|}
\hline & \multirow[b]{2}{*}{ Varieties } & \multicolumn{7}{|c|}{ Water stress treatments } \\
\hline & & $\mathrm{S}_{1}$ & $\mathrm{~S}_{2}$ & $\mathrm{~S}_{3}$ & $\mathrm{~S}_{4}$ & $\mathrm{~S}_{5}$ & Mean & \\
\hline \multirow{7}{*}{$\begin{array}{c}\text { FBY }_{1} \\
\left(\mathrm{~kg} \mathrm{ha}^{-1}\right)\end{array}$} & Kanlow & $94480 \quad \mathrm{a}$ & $77770 \mathrm{c}$ & $62250 \mathrm{f}$ & $36650 \mathrm{j}$ & 19360 о & 58300 a & \\
\hline & Alamo & 87220 b & $72890 \mathrm{~d}$ & $58630 \mathrm{~g}$ & $33380 \mathrm{k}$ & 18650 о & $54150 \mathrm{~b}$ & LSD (0.05) \\
\hline & Shelter & $66650 \mathrm{e}$ & $49280 \mathrm{~h}$ & $39140 \mathrm{j}$ & 299201 & $14500 \mathrm{p}$ & $39900 \mathrm{~d}$ & Variety: 1140 \\
\hline & Trailblazer & $64820 \mathrm{e}$ & $51560 \mathrm{~h}$ & 429601 & $33890 \mathrm{k}$ & 17380 o & $42120 \mathrm{c}$ & Water: 1040 \\
\hline & Cave in rock & $57680 \mathrm{~g}$ & $44480 \quad 1$ & $32360 \mathrm{kl}$ & $23810 \mathrm{n}$ & $11970 \mathrm{p}$ & 33880 e & Variety *water: 2560 \\
\hline & Shawnee & $57060 \mathrm{~g}$ & 423201 & $32570 \mathrm{k}$ & $26860 \mathrm{~m}$ & $13250 \mathrm{p}$ & $34410 \mathrm{e}$ & \\
\hline & Mean & $71330 \mathrm{a}$ & $56380 \mathrm{~b}$ & $44650 \mathrm{c}$ & $30750 \mathrm{~d}$ & $15850 \mathrm{e}$ & 43790 & \\
\hline \multicolumn{9}{|c|}{ F value $(*$ Water stress: 46190; * Variety: $6270 ; *$ Water stress x Variety interaction: 510$)$} \\
\hline \multirow{7}{*}{$\begin{array}{c}\mathbf{D B Y}_{\mathbf{1}} \\
\left(\mathrm{kg} \mathrm{ha}^{-1}\right)\end{array}$} & Shelter & $20880 \mathrm{~cd}$ & $15710 \mathrm{~g}$ & 131201 & $8660 \mathrm{kl}$ & 6170 no & $12910 \mathrm{~d}$ & LSD (0.05) \\
\hline & Alamo & $23810 \mathrm{~b}$ & $20460 \mathrm{~d}$ & 17280 ef & 9110 jk & $7150 \mathrm{mn}$ & $15560 \mathrm{~b}$ & Variety: 470 \\
\hline & Cave in rock & $15720 \mathrm{~g}$ & 126401 & $10150 \mathrm{j}$ & $7040 \mathrm{mn}$ & $4830 \mathrm{p}$ & $10080 \mathrm{f}$ & Water: 740 \\
\hline & Shawnee & $16680 \mathrm{fg}$ & 132001 & $9910 \mathrm{j}$ & $7820 \mathrm{~lm}$ & 5750 op & $10670 \mathrm{e}$ & Variety *water: 1060 \\
\hline & Kanlow & $25120 \mathrm{a}$ & $21630 \mathrm{c}$ & $18300 \mathrm{e}$ & 9660 jk & $7500 \mathrm{~m}$ & $16440 \mathrm{a}$ & \\
\hline & Trailblazer & $21500 \mathrm{~cd}$ & $17840 \mathrm{e}$ & $14430 \mathrm{~h}$ & $10150 \mathrm{j}$ & $7700 \mathrm{~lm}$ & $14320 \mathrm{c}$ & \\
\hline & Mean & $20620 \mathrm{a}$ & $16910 \mathrm{~b}$ & $13860 \mathrm{c}$ & $8740 \mathrm{~d}$ & $6520 \mathrm{e}$ & 13330 & \\
\hline
\end{tabular}

F value (*Water stress: 6460; * Variety: 2360; *Water stress x Variety interactions: 166$)$

$\mathrm{FBY}_{1}$ : First harvest fresh biomass yield $\quad$ DBY $_{1}$ : First harvest dry biomass yield

*: significant at $\mathrm{P} \leq 0.05$. Means followed by the same letters are not different for $\mathrm{P} \leq 0.05$ according to LSD test.

Considering water stress $\mathrm{x}$ variety interactions, in $\mathrm{S}_{1}$ treatments, the lowest and the greatest dry biomass yields were respectively obtained from Cave in rock $(15720 \mathrm{~kg} \mathrm{ha}$ ${ }^{1}$ ) and Kanlow (25120 kg ha ${ }^{-1}$ ) varieties; in $S_{2}$ treatments, from Cave in rock $\left(12640 \mathrm{~kg} \mathrm{ha}^{-1}\right)$ and Kanlow $(21630 \mathrm{~kg}$ $\mathrm{ha}^{-1}$ ) varieties; in $\mathrm{S}_{3}$ treatments, from Shawnee (9910 kg ha
${ }^{1}$ ) and Kanlow (18300 kg ha $\left.{ }^{-1}\right)$ varieties; in $\mathrm{S}_{4}$ treatments, from Cave in rock $\left(7040 \mathrm{~kg} \mathrm{ha}^{-1}\right)$ and Trailblazer $(10150 \mathrm{~kg}$ $\left.\mathrm{ha}^{-1}\right)$ varieties; in $\mathrm{S}_{5}$ treatments without irrigation, from Cave in rock (4830 $\left.\mathrm{kg} \mathrm{ha}^{-1}\right)$ and Trailblazer (7700 kg ha-1) varieties (Figure 1).

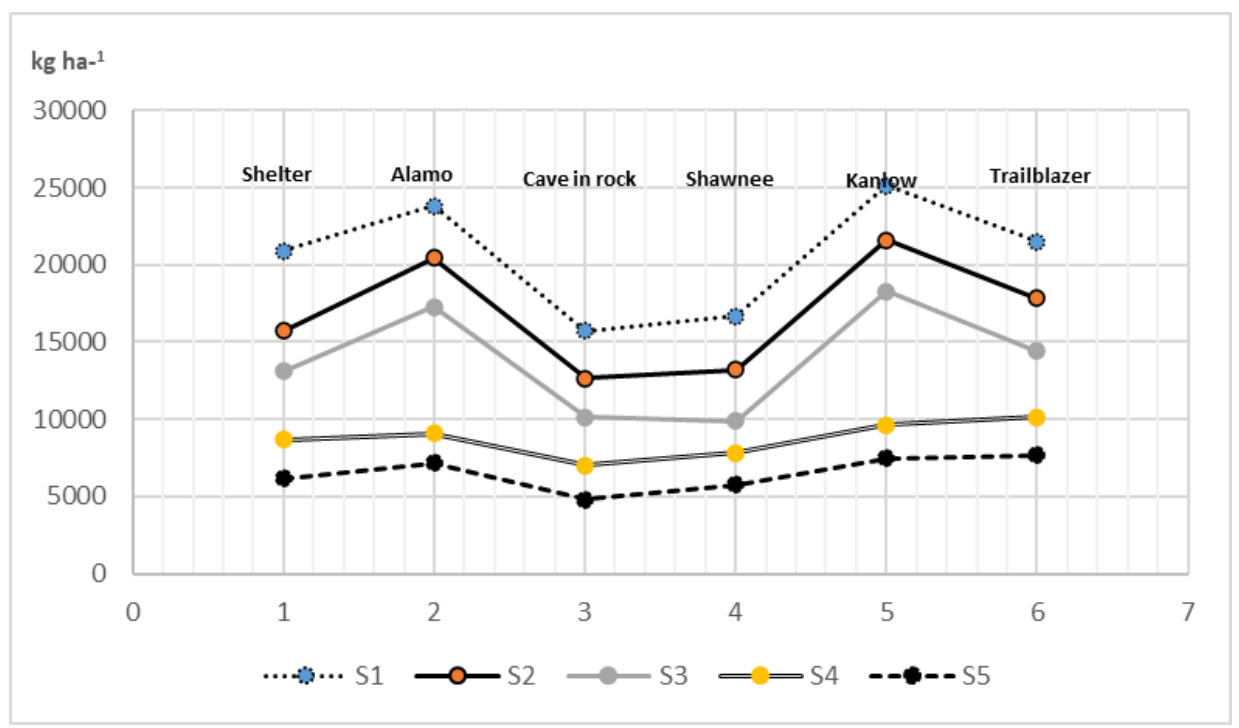

Figure 1. Change in the first harvest dry biomass yields of switchgrass varieties under different water stress levels

As can be inferred from Figure 1, lowland ecotypes of Kanlow and Alamo varieties and upland ecotype of Trailblazer variety had the greatest biomass yields in all water stress treatments and these varieties had greater biomass yields even in $S_{2}$ and $S_{3}$ water stress treatments than full irrigation treatment $\left(S_{1}\right)$ of Shawnee and Cave in rock varieties.

In terms of yield reduction ratios of switchgrass varieties under water stress conditions, Kanlow $\left(\mathrm{S}_{2}: 0.14\right.$ - 
$\left.\mathrm{S}_{5}: 0.70\right)$, Alamo $\left(\mathrm{S}_{2}: 0.14-\mathrm{S}_{5}: 0.70\right)$ and Trailblazer $\left(\mathrm{S}_{2}: 0.17\right.$ - $\left.\mathrm{S}_{5}: 0.64\right)$ varieties had the lowest yield reduction ratios almost in all water stress treatments (Figure 2).

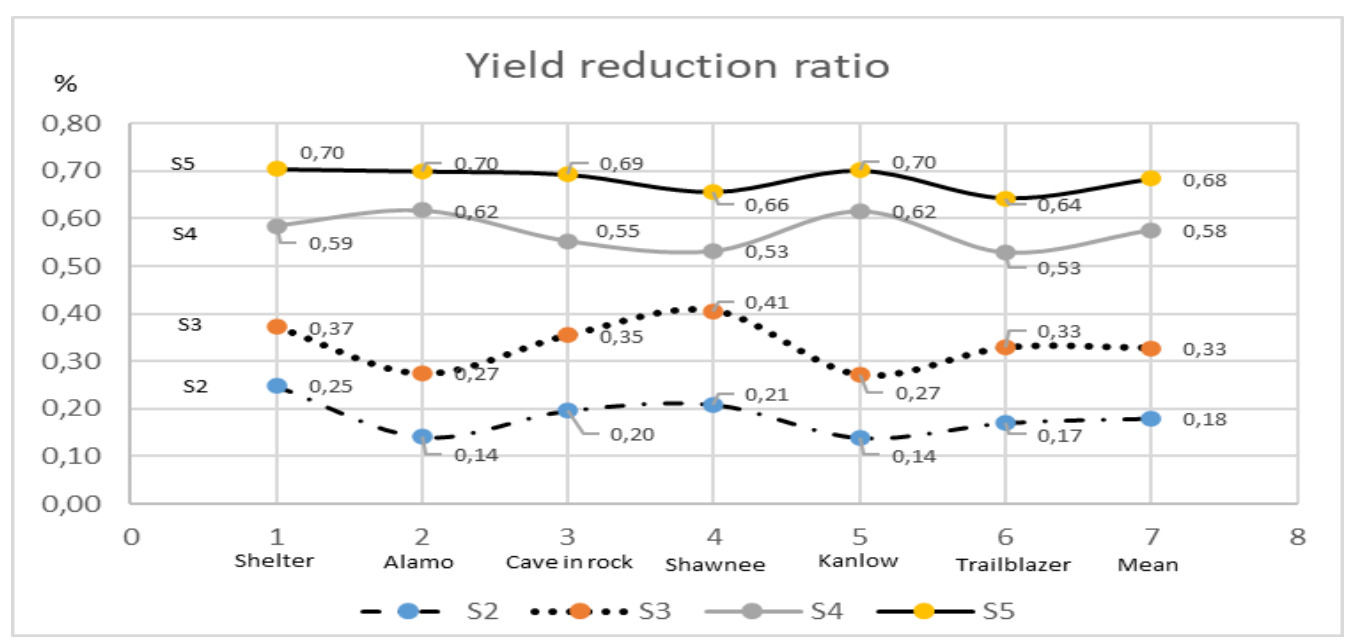

Figure 2. Yield reduction ratios in the first harvest

As it was indicated in previous water stress experiments in switchgrass (Barney et al., 2009; Vamvuka et al., 2010), reductions were observed in switchgrass biomass yields with water stress, however, plants were able to survive under the most severe stress conditions, even in rain-fed conditions (S4 and S5) and able to have certain biomass yields (Table 3). Similarly, Giannoulis et al. (2016) conducted an experiment under irrigated and rain-fed conditions and they reported that dry biomass yield as $14300 \mathrm{~kg} \mathrm{ha}^{-1}$ under irrigated conditions and as $9200 \mathrm{~kg} \mathrm{ha}$ ${ }^{1}$ under rain-fed conditions. In this present experiment, Alamo, Kanlow and Trailblazer varieties were prominent for biomass yield under water stress and rain-fed conditions. Besides high yields in full irrigation, from these varieties was obtained sustainable biomass yields under water stress levels (Figure 1).

Table 3. Second harvest fresh and dry biomass yields $\left(\mathrm{kg} \mathrm{ha}^{-1}\right)$

\begin{tabular}{|c|c|c|c|c|c|c|c|c|}
\hline & \multirow[b]{2}{*}{ Varieties } & \multicolumn{7}{|c|}{ Water stress treatments } \\
\hline & & $\mathrm{S}_{1}$ & $\mathrm{~S}_{2}$ & $\mathrm{~S}_{3}$ & $\mathrm{~S}_{4}$ & $\mathrm{~S}_{5}$ & Mean & \\
\hline \multirow{7}{*}{$\begin{array}{c}\mathbf{F B Y}_{2} \\
\left(\mathrm{~kg} \mathrm{ha}^{-1}\right)\end{array}$} & Shelter & $11680 \mathrm{~cd}$ & $9570 \mathrm{e}$ & $5670 \mathrm{~h}$ & $3430 \mathrm{kl}$ & ---- & $7590 \mathrm{~b}$ & LSD $(0.05)$ \\
\hline & Alamo & 16070 a & $12330 \mathrm{c}$ & $7530 \mathrm{~g}$ & $5850 \mathrm{~h}$ & ---- & $10440 \mathrm{a}$ & Variety: 470 \\
\hline & Cave in rock & 9540 e & $7130 \mathrm{~g}$ & 47901 & $3180 \mathrm{kl}$ & ---- & $6160 \mathrm{~d}$ & Water: 290 \\
\hline & Shawnee & $10180 \mathrm{e}$ & $6890 \mathrm{~g}$ & $4330 \mathrm{ij}$ & $3880 \mathrm{jk}$ & ---- & $6320 \mathrm{~d}$ & Variety *water: 1060 \\
\hline & Kanlow & $11430 \mathrm{~d}$ & $8340 \mathrm{f}$ & $4390 \mathrm{ij}$ & $3660 \mathrm{j}-1$ & ---- & $6950 \mathrm{c}$ & \\
\hline & Trailblazer & $14210 \mathrm{~b}$ & $8350 \mathrm{f}$ & $5080 \mathrm{~h} 1$ & 28801 & ---- & $7630 \mathrm{~b}$ & \\
\hline & Mean & $12180 \mathrm{a}$ & $8770 \mathrm{~b}$ & $5300 \mathrm{c}$ & $3810 \mathrm{~d}$ & ---- & 7520 & \\
\hline
\end{tabular}

F value (*Water stress: 19420; * Variety: 1010;* Water stress x Variety interaction:104)

\begin{tabular}{clllllllll}
\hline & Shelter & $6400 \mathrm{~b}$ & $5380 \mathrm{c}$ & $2960 \mathrm{~g}$ & $1870 \mathrm{k}-\mathrm{m}$ & --- & $4150 \mathrm{a}$ & LSD $(0.05)$ \\
& Alamo & $6910 \mathrm{a}$ & $5010 \mathrm{~cd}$ & $2960 \mathrm{~g}$ & $2510 \mathrm{~h} 1$ & --- & $4350 \mathrm{a}$ & Variety: 210 \\
DBY $_{2}$ & Cave in rock & $4640 \mathrm{~d}$ & $3520 \mathrm{f}$ & $2350 \mathrm{~h}-\mathrm{j}$ & $1520 \mathrm{~m}$ & -- & $3010 \mathrm{~d}$ & Water: 350 \\
$\left(\mathrm{~kg} \mathrm{ha}^{-1}\right)$ & Shawnee & $5310 \mathrm{c}$ & $4710 \mathrm{~d}$ & $2220 \mathrm{1}-\mathrm{k}$ & $1900 \mathrm{k}-\mathrm{m}$ & --- & $3530 \mathrm{c}$ & Variety *water: 420 \\
& Kanlow & $4780 \mathrm{~d}$ & $3520 \mathrm{f}$ & $2020 \mathrm{j}-1$ & $1620 \mathrm{~lm}$ & --- & $2990 \mathrm{~d}$ & \\
& Trailblazer & $7100 \mathrm{a}$ & $4100 \mathrm{e}$ & $2690 \mathrm{gh}$ & $1540 \mathrm{~m}$ & -- & $3860 \mathrm{~b}$ & \\
& Mean & $5860 \mathrm{a}$ & $4370 \mathrm{~b}$ & $2540 \mathrm{c}$ & $1830 \mathrm{~d}$ & --- & 3650 & \\
\hline
\end{tabular}

F value (*Water stress: 3260; * Variety: 597; *Water stress x Variety interactions:116)

$\mathrm{FBY}_{2}$ : Second harvest fresh biomass yield $\quad \mathrm{DBY}_{2}$ : Second harvest dry biomass yield

*: significant at $\mathrm{P} \leq 0.05$. Means followed by the same letters are not different for $\mathrm{P} \leq 0.05$ according to LSD test. 
The regression analysis for water-yield relations of switchgrass varieties is given in Figure 3. There was a linear relationship in all varieties between amount of water irrigation and biomass yields.

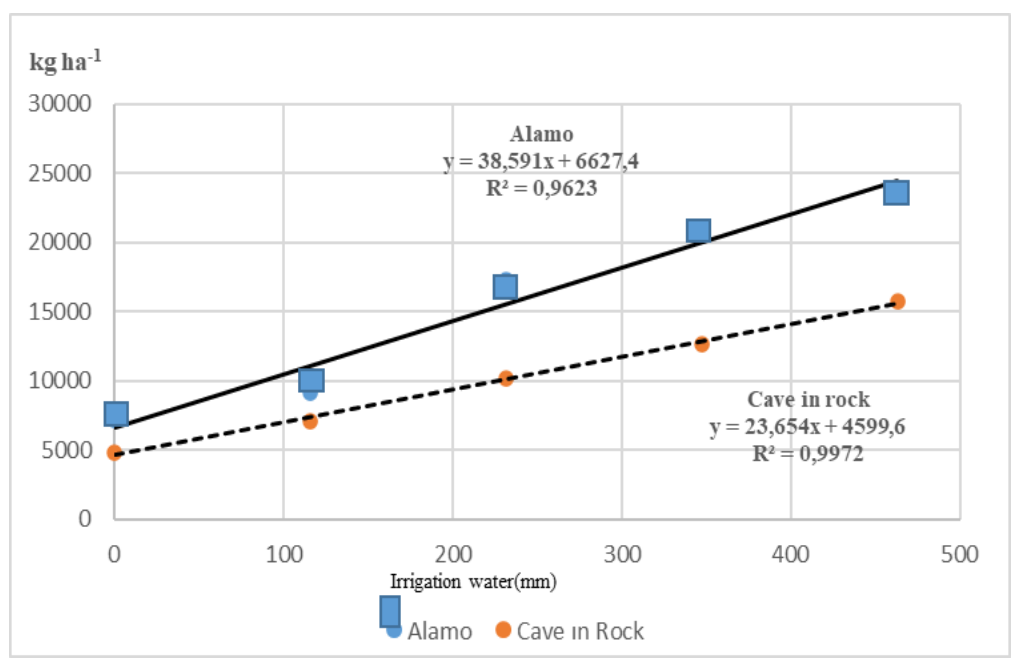

b

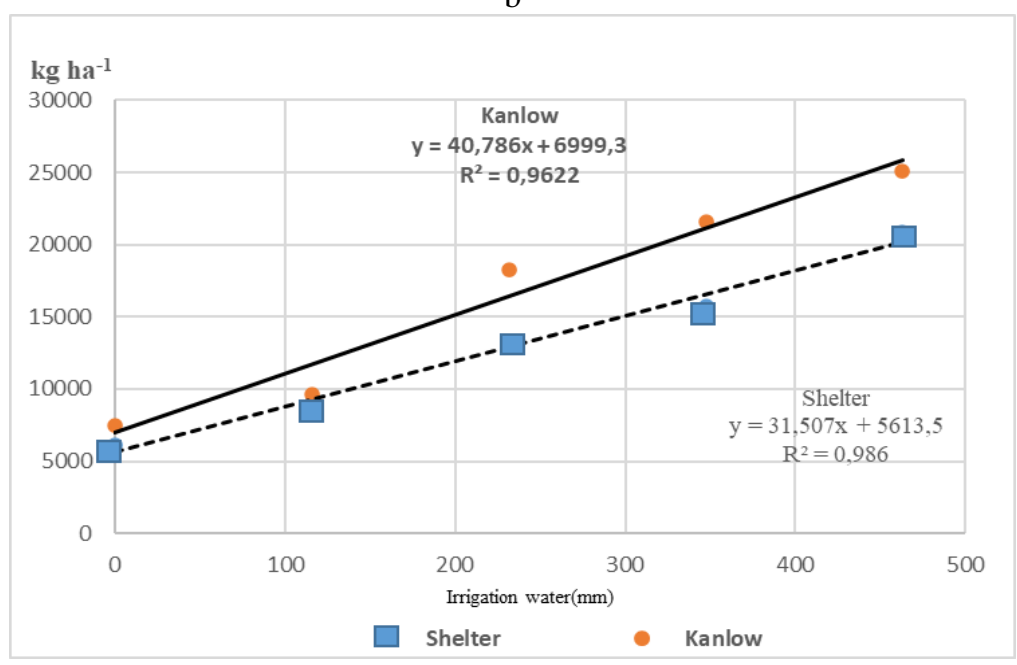

c

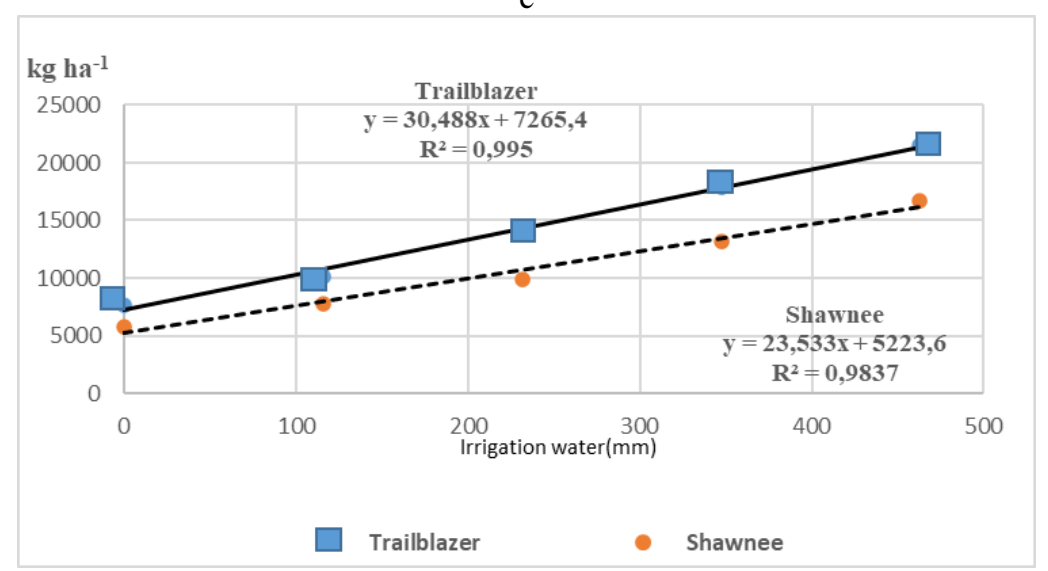

Figure 3. Water - yield relations of switchgrass varieties (a- Regression analysis for Alamo and Cave in rock varieties; b- Regression analysis for Shelter and Kanlow varieties; c- Regression analysis for Trailblazer and Shawnee varieties)

In previous experiments conducted about water stress tolerance of switchgrass varieties, similar with the present findings, better yields were reported especially for Kanlow and Alamo varieties than for the others under stress conditions in several regions (Barney et al., 2009; Aimar et al., 2014; Liu et al., 2015). 


\section{Fresh and dry biomass yields of the second harvest}

Following the first harvest, with the decrease in weather temperatures, the growth of switchgrass varieties has decreased under Konya ecological conditions. As the average of two years, second harvest fresh and dry biomass yields of the switchgrass varieties are given in Table 3.

As it was in the first harvest and as indicated also in previous experiments, decreasing biomass yields were observed with decreasing amount of irrigation water in second harvest (Vamvuka et al., 2010).

As the average of two years, in the second harvest, the lowest and the greatest fresh biomass yields were respectively obtained from Cave in rock $\left(6160 \mathrm{~kg} \mathrm{ha}^{-1}\right)$ and Alamo (10440 $\left.\mathrm{kg} \mathrm{ha}^{-1}\right)$ varieties; the lowest and the greatest dry biomass yields were respectively obtained from Kanlow (2990 kg ha ${ }^{-1}$ ) and Alamo (4350 kg ha ${ }^{-1}$ ) varieties (Table 3).

Second cutting biomass yield values obtained from this experiment are similar to the yield results obtained by Soylu et al. (2010). They reported that second harvest dry biomass yields varied between $1180 \mathrm{~kg} \mathrm{ha}^{-1}$ (Kanlow) and $4250 \mathrm{~kg} \mathrm{ha}^{-1}$ (Shelter). In present experiment, single harvest was made in rain-fed treatment without irrigation $\left(\mathrm{S}_{5}\right)$ (Table 3). Number of harvest in switchgrass vary with the purpose of cultivation, irrigation conditions and ecological conditions; single harvest is made especially in water deficit conditions and in cultivation for bioethanol production (Sanderson et al. 1999; Soylu et al., 2010). With regard to variety performance under water stress conditions, in $S_{1}$ treatments, the lowest and the greatest second harvest dry biomass yields were respectively obtained from Cave in rock (4640 kg ha-1) and Trailblazer $\left(7100 \mathrm{~kg} \mathrm{ha}^{-1}\right)$ varieties; in $\mathrm{S}_{2}$ treatments, from Cave in rock and Kanlow (3520 kg ha-1) and Alamo (5010 kg ha ${ }^{-1}$ ) varieties; in $S_{3}$ treatments, from Kanlow $\left(2020 \mathrm{~kg} \mathrm{ha}^{-1}\right)$ and Alamo and Shelter $\left(2960 \mathrm{~kg} \mathrm{ha}^{-1}\right)$ varieties; in $\mathrm{S}_{4}$ treatments, from Cave in rock $\left(1520 \mathrm{~kg} \mathrm{ha}^{-1}\right)$ and Alamo (2510 kg ha$\left.{ }^{1}\right)$ varieties. In present the experiment, in both years, the first harvest was made at the end of July and the second growth season included August and September. In this experiment, since there is not enough precipitation in both years in August biomass yields reduced in water stress treatments. Early Autumn frosts of the region also influenced second harvest biomass yields.

Irrigation water use efficiency (IWUE) was calculated as $5.7 \mathrm{~kg} \mathrm{~m}^{-3}$ for the first harvest and as $2.1 \mathrm{~kg} \mathrm{~m}^{-3}$ for the second harvest (Table 5). These values indicated that for irrigation second harvest was not economic and sustainable in present research site and similar ecologies with deficit water resources. Thus, single cutting is recommended for the semi-arid conditions.

\section{Plant height}

As the average of two years, plant height was measured as $130 \mathrm{~cm}$. Plant heights of water stress treatments varied between $70 \mathrm{~cm}\left(\mathrm{~S}_{5}\right)$ and $180 \mathrm{~cm}\left(\mathrm{~S}_{1}\right)$. Alexopoulou et al. (2017) reported the average plant height of switchgrass varieties as $152 \mathrm{~cm}$ in their experiment conducted in the marginal lands of Greece. In this the experiment result, as it was in biomass yield, decreasing plant heights were observed with increasing water stress levels. While plant heights of full irrigation $\left(S_{1}\right)$ and $S_{2}$ treatments were close to each other, height difference and relative decrease in plant heights were more remarkable in increasing water stress treatments $\left(S_{3}, S_{4}\right.$ and $\left.S_{5}\right)$ (Table 4). Supporting the results of this experiment, Giannoulis et al. (2016) reported that decreasing plant heights of switchgrass varieties under water stress and reported average plant height as $193 \mathrm{~cm}$ under irrigated conditions and as $131 \mathrm{~cm}$ under rain-fed conditions. Similarly, Soylu et al. (2010) reported plant height of lowland ecotype Kanlow variety in the third year as $186 \mathrm{~cm}$ and upland ecotype of Blackwell variety as 132 $\mathrm{cm}$ under irrigated conditions; reported plant height as 78 $\mathrm{cm}$ for Kanlow variety and as $63 \mathrm{~cm}$ for Blackwell variety under rain-fed conditions. Both the peresent experiment and previous experiment results indicated that plant heights decreased under in water stress conditions and lowland ecotypes had greater plant heights.

As can be inferred from Table 4, as the average of two years, plant heights of switchgrass varieties varied between $121 \mathrm{~cm}$ (Shawnee) and $151 \mathrm{~cm}$ (Alamo). The greatest plant heights were observed in lowland ecotypes of Kanlow and Alamo varieties. Alexopoulou et al. (2017) reported average plant height as $164 \mathrm{~cm}$ for lowland ecotypes and as $137 \mathrm{~cm}$ for upland ecotypes.

Considering the water stress $\mathrm{x}$ variety interactions, as the average of two years, plant heights varied between 152 $\mathrm{cm}$ (Trailblazer) and $209 \mathrm{~cm}$ (Kanlow and Alamo) in $\mathrm{S}_{1}$ treatments; between $142 \mathrm{~cm}$ (Trailblazer) and $185 \mathrm{~cm}$ (Kanlow) in $\mathrm{S}_{2}$ treatments; between $121 \mathrm{~cm}$ (Trailblazer) and $163 \mathrm{~cm}$ (Kanlow) in $\mathrm{S}_{3}$ treatments; between $94 \mathrm{~cm}$ (Trailblazer) and $115 \mathrm{~cm}$ (Alamo) in $\mathrm{S}_{4}$ treatments; between $59 \mathrm{~cm}$ (Cave in rock) and $87 \mathrm{~cm}$ (Kanlow) in $S_{5}$ treatments (Table 4). In general, Kanlow and Alamo varieties yielded greater plant heights in all water stress treatments than the upland ecotypes.

\section{Number of stalks per meter}

As the average of two years, number of stalks per meter of water stress treatments varied between 221 stalks $\left(\mathrm{S}_{5}\right)$ and 356 stalks $\left(\mathrm{S}_{1}\right)$. As it was in biomass yields and yield components, number stalks per meter decreased with increasing water stress. Since number of stalks per meter affect biomass yield, values obtained under rain-fed conditions indicated that switchgrass was also a promising forage crop under arid and semi-arid conditions. As the average of two years, number of stalks per meter of varieties varied between 272 stalks (Alamo) and 337 stalks (Trailblazer). Since switchgrass is a perennial crop, number of stalks per meter in establishment year and subsequent years ( 2 and more) largely depend on climate, soil and soil conditions, agronomic practices and tillering capacities. Increasing number of stalks per meter also increase biomass yields and the other yield components. 
Table 4. Agronomic traits of switchgrass varieties in different treatments

\begin{tabular}{|c|c|c|c|c|c|c|c|c|}
\hline & \multirow[b]{3}{*}{ Varieties } & \multirow{2}{*}{\multicolumn{7}{|c|}{ Water stress treatments }} \\
\hline & & & & & & & & \\
\hline & & $\mathrm{S}_{1}$ & $\mathrm{~S}_{2}$ & $\mathrm{~S}_{3}$ & $\mathrm{~S}_{4}$ & $\mathrm{~S}_{5}$ & Mean & \\
\hline \multirow{7}{*}{$\begin{array}{c}\mathrm{PH} \\
(\mathrm{cm})\end{array}$} & Shelter & $171 \mathrm{c}$ & $148 \mathrm{fg}$ & $124 \mathrm{ij}$ & $95 \mathrm{~m}$ & $68 \mathrm{p}$ & $121 \mathrm{c}$ & LSD $(0.05)$ \\
\hline & Alamo & 209 a & $185 \mathrm{~b}$ & $161 \mathrm{de}$ & $115 \mathrm{kl}$ & 83 o & $151 \mathrm{a}$ & Variety: 3.4 \\
\hline & Cave in rock & $171 \mathrm{c}$ & $162 \mathrm{~d}$ & $138 \mathrm{~h}$ & $96 \mathrm{~m}$ & $59 \mathrm{q}$ & $125 \mathrm{~b}$ & Water: 8.7 \\
\hline & Shawnee & $167 \mathrm{~cd}$ & 154 ef & 1291 & $90 \mathrm{~m}-\mathrm{o}$ & $63 \mathrm{pq}$ & $121 \mathrm{c}$ & Variety *water: 7.7 \\
\hline & Kanlow & 209 a & $179 \mathrm{~b}$ & $163 \mathrm{~d}$ & 1131 & 87 no & $150 \mathrm{a}$ & \\
\hline & Trailblazer & $152 \mathrm{f}$ & $142 \mathrm{gh}$ & $121 \mathrm{jk}$ & $94 \mathrm{mn}$ & $61 \mathrm{pq}$ & $114 \mathrm{~d}$ & \\
\hline & Mean & $180 \mathrm{a}$ & $161 \mathrm{~b}$ & $139 \mathrm{c}$ & $100 \mathrm{~d}$ & $70 \mathrm{e}$ & 130 & \\
\hline \multicolumn{9}{|c|}{ F value (*Water stress: $284 ; *$ Variety: $169 ; *$ Water stress x Variety interaction: 5.7$)$} \\
\hline \multirow{7}{*}{$\begin{array}{c}\mathrm{NS} \\
\text { (number/m²) }\end{array}$} & Shelter & 405 a & $384 \mathrm{a}-\mathrm{c}$ & $338 \mathrm{~d}-\mathrm{g}$ & $293 \mathrm{~h}-\mathrm{j}$ & $210 \mathrm{~m}$ & 326 a & $\operatorname{LSD}(0.055)$ \\
\hline & Alamo & $342 \mathrm{~d}-\mathrm{f}$ & $2831-\mathrm{k}$ & $309 \mathrm{f}-1$ & $218 \mathrm{~m}$ & $209 \mathrm{~m}$ & $272 \mathrm{c}$ & Variety: 15.7 \\
\hline & Cave in rock & 318 e-h & $305 \mathrm{~g}-1$ & $288 \mathrm{~h}-\mathrm{k}$ & $257 \mathrm{kl}$ & $213 \mathrm{~m}$ & $276 c$ & Water: 14.7 \\
\hline & Shawnee & $340 \mathrm{~d}-\mathrm{f}$ & $336 \mathrm{~d}-\mathrm{g}$ & 296 h1 & $280 \quad 1-\mathrm{k}$ & $221 \mathrm{~m}$ & $294 \mathrm{~b}$ & Variety *water: 35.2 \\
\hline & Kanlow & $366 \mathrm{~b}-\mathrm{d}$ & 386 a-c & $2811-\mathrm{k}$ & $257 \mathrm{kl}$ & $209 \mathrm{~m}$ & $300 \mathrm{~b}$ & \\
\hline & Trailblazer & $363 \mathrm{~b}-\mathrm{d}$ & $391 \mathrm{ab}$ & 352 c-e & $314 \mathrm{f}-1$ & $266 \mathrm{kl}$ & $337 \mathrm{a}$ & \\
\hline & Mean & $356 \mathrm{a}$ & $347 \mathrm{a}$ & $310 \mathrm{~b}$ & $270 \mathrm{c}$ & $221 \mathrm{~d}$ & 301 & \\
\hline \multicolumn{9}{|c|}{ F value $(*$ Water stress: $103 ; *$ Variety: $26.5 ; *$ Water stress x Variety interaction: 3.4$)$} \\
\hline \multirow{7}{*}{$\begin{array}{l}\text { SW } \\
(\mathrm{g})\end{array}$} & Shelter & $1.93 \mathrm{de}$ & $1.37 \mathrm{~h}-\mathrm{j}$ & $1.19 \mathrm{jk}$ & $0.70 \mathrm{~m}-\mathrm{o}$ & 0.61 n-p & $1.16 \mathrm{bc}$ & LSD (0.05) \\
\hline & Alamo & $3.48 \mathrm{a}$ & $2.20 \mathrm{c}$ & $2.08 \mathrm{~cd}$ & $1.251-\mathrm{k}$ & 0.69 no & $1.94 \mathrm{a}$ & Variety: 1.09 \\
\hline & Cave in rock & $1.60 \mathrm{f}-\mathrm{h}$ & $1.53 \mathrm{gh}$ & 1.44 h1 & $0.83 \mathrm{mn}$ & $0.40 \mathrm{p}$ & $1.16 \mathrm{bc}$ & Water: 0.12 \\
\hline & Shawnee & $1.91 \mathrm{de}$ & $1.73 \mathrm{e}-\mathrm{g}$ & $1.211-\mathrm{k}$ & $0.94 \mathrm{~lm}$ & 0.51 op & $1.26 \mathrm{~b}$ & Variety $*_{\text {water: }} 0.24$ \\
\hline & Kanlow & $2.81 \mathrm{~b}$ & $2.79 \mathrm{~b}$ & $2.25 \mathrm{c}$ & $0.94 \mathrm{~lm}$ & $0.77 \mathrm{mn}$ & $1.91 \mathrm{a}$ & \\
\hline & Trailblazer & $1.80 \mathrm{ef}$ & $1.251-\mathrm{k}$ & $1.09 \mathrm{kl}$ & $0.72 \mathrm{~m}-\mathrm{o}$ & $0.42 \mathrm{p}$ & $1.06 \mathrm{c}$ & \\
\hline & Mean & $2.25 \mathrm{a}$ & $1.81 \mathrm{~b}$ & $1.55 \mathrm{c}$ & $0.90 \mathrm{~d}$ & $0.56 \mathrm{e}$ & 1.42 & \\
\hline
\end{tabular}

PH: Plant height; NS: Number of stalks; SW: Single stalk weight

*: significant at $\mathrm{P} \leq 0.05$. Means followed by the same letters are not different for $\mathrm{P} \leq 0.05$ according to LSD test.

Table 5. IWUE values $\left(\mathrm{kg} \mathrm{m}^{-3}\right)$ calculated with the use averages of dry biomass yields

\begin{tabular}{lcccccccccc}
\hline & \multicolumn{4}{c}{ First harvest IWUE $\left(\mathbf{k g ~ m}^{-\mathbf{3}}\right)$} & \multicolumn{4}{c}{ Second harvest IWUE $\left(\mathbf{k g ~ \mathbf { ~ m } ^ { - 3 } )}\right.$} \\
\hline Variety /water stress & $\mathrm{S}_{1}$ & $\mathrm{~S}_{2}$ & $\mathrm{~S}_{3}$ & $\mathrm{~S}_{4}$ & Average of varieties & $\mathrm{S}_{1}$ & $\mathrm{~S}_{2}$ & $\mathrm{~S}_{3}$ & $\mathrm{~S}_{4}$ & Average of varieties \\
\hline Shelter & 4.5 & 4.5 & 5.7 & 7.5 & 5.5 & 2.2 & 2.5 & 2.1 & 2.6 & 2.3 \\
Alamo & 5.1 & 5.9 & 7.5 & 7.9 & 6.6 & 2.4 & 2.3 & 2.1 & 3.5 & 2.6 \\
Cave in Rock & 3.4 & 3.6 & 4.4 & 6.1 & 4.4 & 1.6 & 1.6 & 1.6 & 2.1 & 1.7 \\
Shawnee & 3.6 & 3.8 & 4.3 & 6.7 & 4.6 & 1.8 & 2.2 & 1.5 & 2.6 & 2.0 \\
Kanlow & 5.4 & 6.2 & 7.9 & 8.3 & 7.0 & 1.7 & 1.6 & 1.4 & 2.2 & 1.7 \\
Trailblazer & 4.6 & 5.1 & 6.2 & 8.8 & 6.2 & 2.5 & 1.9 & 1.9 & 2.1 & 2.1 \\
\hline
\end{tabular}

In this experiment, upland ecotypes had greater number of stalks per meter than the lowland ecotypes. Similarly, Geren et al. (2016) and Sauerbeck et al. (2002), reported had greater number of stalks per meter for upland ecotypes.

Different from the results of this experiment, Min et al. (2017) in an experiment conducted in the USA with 22 varieties, they reported that the greatest and the lowest number of stalks as 26.8 stalks per plant (Alamo) and 23.5 stalks per plant (Cave in rock), respectively. Such differences were mainly caused from morphological characteristics, ecological conditions, soil and climate factors and growing techniques (Cassida et al., 2005; Nasso et al., 2015).

According to Table 4, in terms of water stress $\mathrm{x}$ variety interactions, the greatest and the lowest number of stalks per meter were respectively obtained from Kanlow (366 stalks) and Cave in rock (318 stalks) varieties in $S_{1}$ treatments; from Trailblazer (391 stalks) and Alamo (283 stalks) varieties in $S_{2}$ treatments; from Trailblazer (352 stalks) and Kanlow (281 stalks) varieties in $\mathrm{S}_{3}$ treatments; from Trailblazer (314 stalks) and Cave in rock (218 stalks) varieties in $\mathrm{S}_{4}$ treatments; from Trailblazer (266 stalks) and Cave in rock and Kanlow (209 stalks) varieties in $\mathrm{S}_{5}$ treatments. In water stress treatments, lowland ecotypes had lower number of stalks per meter than the upland ecotypes. Similarly, Soylu et al. (2010) investigated yield and yield components (SDs) in different switchgrass varieties on Konya ecological conditions. They reported that number of stalks per meter of Kanlow variety as 218 stalks per meter under irrigated conditions and as 89 stalks per meter under rain-fed conditions, also reported number 
of stalks per meter for upland ecotype Blackwell variety as 313 stalks per meter under irrigated conditions and as 188 stalks per meter under rain- fed conditions.

\section{Single stalk weight}

Single stalk weights decreased with water stress. As the average of two years, single stalk weights of the water stress conditions varied between $0.56 \mathrm{~g}\left(\mathrm{~S}_{5}\right)$ and $2.25 \mathrm{~g}\left(\mathrm{~S}_{1}\right)$. Again, as the average of two years, single stalk weights of the varieties varied between $1.06 \mathrm{~g}$ (Trailblazer) and $1.94 \mathrm{~g}$ (Alamo) (Table 4).

As can be inferred from Table 4, lowland varieties (Kanlow and Alamo) had greater single stalk weights than upland varieties. Kanlow and Alamo varieties are mostly used for bioethanol production and erosion control, thus they had greater plant heights and single stalk weights than the other varieties. When the biomass yields and single stalk weights of lowland ecotypes were assessed together, it was observed that these varieties with high biomass yields also had greater single stalk weights than the other varieties. Besides, Trailblazer variety with a low single stalk weight had a high biomass yield because of greater number of stalks per meter of this varieties. In present experiment, four upland varieties had lower single stalk weights than the lowland varieties and these varieties are mostly used as forage crop. Similarly, Cicek (2017) reported that fresh single stalk weights as $16.8 \mathrm{~g}$ for Alamo variety and as $10.1 \mathrm{~g}$ for Cave in rock variety. Present findings on single stalk weights also comply with the findings of earlier experiments conducted in different ecologies (Madakadze et al., 1998; Alexpoulou et al., 2002).

Considering the interactions (Water stress * varieties), Kanlow and Alamo varieties had greater single stalk weights in all water stress treatments than the upland varieties. Single stalk weight of lowland varieties were less influenced by water stress, thus had greater single stalk weights and consequently greater biomass yields in water deficit regions or non-irrigated sites as compared to upland varieties. Similar with the present findings, Soylu et al. (2010) reported that fresh single stalk weight of Kanlow variety as $10.8 \mathrm{~g}$ under irrigated conditions and as $3.3 \mathrm{~g}$ under rain-fed conditions and single stalk weight of Blackwell variety as $6.4 \mathrm{~g}$ under irrigated conditions and as $1.6 \mathrm{~g}$ under rain-fed conditions.

\section{Irrigation water use efficiency}

Ratio of biomass or grain yield of a plant to amount of irrigation water applied to get this yield is so called as irrigation water use efficiency (IWUE). High IWUE values indicate greater yields per unit of water applied. In present experiment, two-year averages of dry biomass yield in the first and second harvest were used and IWUE values were separately calculated (Table 5).

As can be inferred from Table 5, the lowest and the greatest IWUE values in the first harvest were respectively obtained from Cave in rock $\left(3.4 \mathrm{~kg} \mathrm{~m}^{-3}\right)$ and Kanlow (5.4 $\mathrm{kg} \mathrm{m}^{-3}$ ) varieties in $S_{1}$ treatments; from Cave in rock (3.6 $\mathrm{kg} \mathrm{m}^{-3)}$ and Kanlow $\left(6.2 \mathrm{~kg} \mathrm{~m}^{-3}\right)$ varieties in $S_{2}$ treatments; from Shawnee $\left(4.3 \mathrm{~kg} \mathrm{~m}^{-3}\right)$ and Kanlow $\left(7.9 \mathrm{~kg} \mathrm{~m}^{-3}\right)$ varieties in $\mathrm{S}_{3}$ treatments; from Cave in rock $\left(6.1 \mathrm{~kg} \mathrm{~m}^{-3}\right)$ and Trailblazer $\left(8.8 \mathrm{~kg} \mathrm{~m}^{-3}\right)$ varieties in $\mathrm{S}_{4}$ treatments. When all water stress treatments were assessed together, it was observed that dry matter yield per unit water increased with decreasing amount of irrigation water. Kanlow variety had the greatest dry matter production per unit of water in all irrigation treatments. In this case, Kanlow variety had the greatest dry biomass production per unit of water both in full irrigation and water stress treatments, thus this variety could be recommended for both irrigated and rainfed conditions.

The lowest and the greatest IWUE values of the second harvest were respectively obtained from Cave in rock (1.6 $\left.\mathrm{kg} \mathrm{m} \mathrm{m}^{-3}\right)$ and Trailblazer $\left(2.5 \mathrm{~kg} \mathrm{~m}^{-3}\right)$ varieties in $\mathrm{S}_{1}$ treatments; from Cave in rock and Kanlow $\left(1.6 \mathrm{~kg} \mathrm{~m}^{-3}\right)$ and Shelter $\left(2.5 \mathrm{~kg} \mathrm{~m}^{-3}\right)$ varieties in $\mathrm{S}_{2}$ treatments; from Kanlow $\left(1.4 \mathrm{~kg} \mathrm{~m}^{-3}\right)$ and Shelter and Alamo $\left(2.1 \mathrm{~kg} \mathrm{~m}^{-3}\right)$ varieties in $\mathrm{S}_{3}$ treatments; from Cave in rock and Trailblazer $\left(2.1 \mathrm{~kg} \mathrm{~m}^{-}\right.$ ${ }^{3}$ ) and Alamo $\left(3.5 \mathrm{~kg} \mathrm{~m}^{-3}\right)$ varieties in $\mathrm{S}_{4}$ treatments. In second harvest, when all water stress treatments were assessed together, the greatest dry biomass production per unit of consumed irrigation water varied with the varieties. The greatest IWUE values in full irrigation were obtained in Trailblazer variety and the greatest values in $\mathrm{S}_{4}, \mathrm{~S}_{3}$ and $\mathrm{S}_{2}$ water stress treatments were respectively obtained in Alamo and Shelter varieties (Table 5). With this experiment, it was concluded that the Alamo variety had the highest biomass yield under water stress conditions in the second harvest.

IWUE is a significant parameter for water deficit regions. Selection, adaptation and widespread of species and varieties more efficiently using irrigation water and thus able to produce greater quantities of biomass per unit of water are significant issues for sustainability of agricultural practices in these regions. Since switchgrass is mostly grown under rain-fed conditions with precipitations throughout the growing season, water-yield relations, thus irrigation water use efficiencies should be well identified.

IWUE values of the second harvest were quite lower than the values of the first harvest. Therefore, considering the current water deficits and irrigation costs, it is recommended to be irrigated of switchgrass plants until the first harvest and not to irrigate after the first harvest in Konya ecological conditions.

\section{CONCLUSION}

The experiment results have shown that switchgrass, which is a new plant for Turkey, was well adapted to ecological conditions of Konya province and was able to produce quite significant quantities of biomass. Switchgrass plants was used irrigation water quite efficiently and produced high biomass quantities both under irrigated and rain-fed conditions. Trailblazer variety, mostly used as forage crop and Kanlow and Alamo varieties, commonly used for bioethanol production and erosion prevention have had high biomass yields and IWUE values in all water stress treatments. The experiment 
results could be used in further experiments to be conducted over the marginal lands.

\section{LITERATURE CITED}

Alexopoulou, E., N. Sharma, M. Christou, I. Piscioneri, M. Mardikis and V. Pigniatelli. 2002. Switchgrass in the Mediterranean region. Final Report. see www.switchgrass.nl. (Accessed 10.01.2020).

Alexopoulou, E., F. Zanetti, E.G. Papazoglou, M. Christou, Y. Papatheohari, K. Tsiotas and I. Papamichael. 2017. Long-term studies on switchgrass grown on a marginal area in Greece under different varieties and nitrogen fertilization rates. Industrial Crops \& Products107: 446-452.

Aimar, D., M. Calafat, A.M. Andrade, L. Carassay, F. Bouteau, G. Abdala and M.L. Molas. 2014. Drought effects on the early development stages of Panicum virgatum L.: Cultivar differences. Biomass and Bioenergy 66: 49-59.

Araghi, S.G. and M.T. Assad. 1998. Evaluation of four screening techniques for drought resistance and their relationship to yield reduction ratio in wheat. Euphytica 103: 293-299.

Anonymous, 2009. Problems of Konya closed basin groundwater and solutions. Konya Chamber of Geological Engineers publications (News bulletin p: 78-81). (Accessed 01.10.2019).

Barney, J.N., J.J. Mann, G.B. Kayser, E. Blumwald, A.V. Deynze and J.M. Ditomaso. 2009. Tolerance of switchgrass to extreme soil moisture stress: Ecological implications. Plant Science. 177: 732.

Cassida, K.A., J.P. Muir, M.A. Hussey, J.C. Read, B.C. Venuto and W.R. Ocumpaugh. 2005. Biofuel component

concentrations and yields of switchgrass in South Central U.S. 692. Environments Crop Science 45 (2): 682-

Cicek, F. 2017. The determination of G.D.D. for different morphological stages and physiological characteristics

of cutting times of switchgrass varieties (Panicum virgatium L.). Selcuk University Natural an Applied Sciences Department Master Thesis. Pages: 24-43.

Geren, H., Y.T. Kavut and G.D. Topcu. 2016. A preliminary study on the biomass yield and some agronomical characteristics of different switch grass genotypes grown under Bornova ecological conditions. 2. National Biofuels Symposium. Samsun/Turkey. Pages: 286-292.

Giannoulis, K.D., T. Karyotis, M.M. Sakellariou, L. Bastiaans, P.C. Struik and N.G. Danalatos. 2016. Switchgrass

biomass partitioning and growth characteristics under different management practices. NJAS- Wageningen J.Life Sci. (2016), http://dx.doi.org/10.1016/j.njas.2016.03.011

Howell, T.A., R.H. Cuencaand and K.H. Solomon. 1990. Crop yield response. "Manegement of farm irrigation systems. Edit. G.J. Hoffman., T.A. Howell., K.H. Solomon." Chap. 5. An ASAE Monograph. Pages: 93-

116.

Kara, M. 2011. Irrigation and irrigation facilities. Selcuk University publications. Pages: 45-65.

Liu, Y., X. Zhang, H. Tran, L. Shan, J. Kim, K. Childs, E.H. Ervin, T. Frazier and B. Zhao. 2015. Assessment of drought tolerance of 49 switchgrass genotypes using physiological and morphological parameters. Biotechnology for Biofuel 8 (1): 152 .
Ma, Z., C.V. Wood and D.I. Bransby. 2000. Soil management impacts on soil carbon sequestration by switchgrass. Biomass and Bioenergy 18 (6): 469-477.

Madakadze, I.C., B.E. Coulman, P. Peterson, K.A. Stewart, R. Samson and D.L. Smith. 1998. Leaf area development, light interception, and yield among switchgrass populations in a short-season area. Crop Science 38 (3): 827-834.

Min, D., Y.N. Guragain, V. Prasad, P.V. Vadlaniand and J. Lee. 2017. Effects of different genotypes of switchgrass

as a bioenergy crop on yield components and bioconversion potential. Journal of Sustainable Bioenergy systems 7: 27-35.

Muir, J.P., M.A. Sanderson, W.., Ocumpaugh, R.M. Jones and R.L. Reed. 2001. Biomass production of 'Alamo' switchgrass in response to nitrogen, phosphorus, and row spacing. Agronomy Journal 93 (4): 96-901.

Nasso, N.N.D., M.V. Lasorella, N. Roncucci and E. Bonari. 2015. Soil texture and crop management affect switchgrass productivity in the Mediterranean. Industrial Crops and Products 65: 21-26.

Parrish, D.J. and J.H. Fike. 2005. The biology and agronomy of switchgrass for biofuels. Critical Reviews in Plant Sciences 24 (5-6): 423-459.

Sanderson, M.A., J.C. Readand and R.L. Reed. 1999. Harvest management of switchgrass for biomass feedstock

and forage production. Agronomy Journal 91 (1): 5-10.

Sauerbeck, G., W. Bacher, N. El Bassam, W. Elbersen, V. Pignatelli, I. Piscioneri and N. Sharma. 2002. Effects

of different seeding rates, drilling dates and weed control on establishment of switchgrass varieties in nothern Germany and Southern Italy. Final Report FAIR 5-CT97-3701, www.switchgrass. nl. (Accessed

10.02.2020)

Seflek, A. 2010. The determination of yield, some morphological,phenogical and physiological characteristics of

switchgrass varieties (Panicum virgatum L.). Selcuk University Natural and Applied Sciences Department Master Thesis. Pages: 26-42.

Soylu, S., B. Sade, H. Ogut, F. Akınerdem, M. Babaoglu, R. Ada, T. Eryılmaz, O. Ozturk and H. Oguz. 2010. Investigation of agronomic potential of switchgrass as an alternative biofuel and biomass crop for Turkey.18th European Biomass Conforence, Lyon Fransa.

Steel, R.G.D. and J.H. Torrie. 1980. Principles and procedures of statistics. McGraw-Hill, New York.

Vamvuka, D., V. Topouzi and S. Sfakiotakis. 2010. Evaluation of production yield and thermal processing of switchgrass as a bio-energy crop for the Mediterranean region. Fuel Processing Technology 91 (9): 988-

996

Wullschleger, S.D., E.B. Davis, M.E. Borsuk, C.A. Gunderson and L.R. Lynd. 2010. Biomass production in switchgrass across the United States: database description and determination of yield. Crop Sci. 102, 1158-1168.

Xu, B., F., Li, L. Shan, Y. Ma, N. Ichızen and J. Huang. 2006. Gas exchange, biomass partition, and water relationships of three grass seedlings under water stress. Weed Biology and Management. 6 (2): 79-88.

Zhu, Y., X., Fan, X. Hou, J. Wu and T. Wang. 2014. Effect of different levels of nitrogen deficiency on switchgrass seedling growth. The Crop Journal 2 (4): 223-234. 